\title{
Investigating sine-band hysteresis control of photovoltaic-grid connected inverter
}

\author{
M. Della Krachai ${ }^{1}$, K. Melouk ${ }^{2}$, M. Keddar ${ }^{3}$ \\ ${ }^{1,2}$ Automatics department, University of Science and Technologies of Oran - Mohamed Boudiaf, Algeria \\ ${ }^{3}$ Department of Electrical and Computer Engineering Université du Québec à Trois-Rivières, Canada
}

\begin{tabular}{l}
\hline Article Info \\
\hline Article history: \\
Received Aug 6, 2019 \\
Revised Oct 20, 2019 \\
Accepted Dec 15, 2019 \\
\hline
\end{tabular}

Keywords:

Artificial intelligence

Distributed generators

Maximal power extraction

PV-grid connected system

Sine-band hysteresis control

\begin{abstract}
In this paper, an optimization of PV grid connected system is investigated. This is achieved by considering the application of artificial intelligence in the DC side to realize maximal power extraction, and using a sine-band hysteresis control in the $\mathrm{AC}$ side of the system, to generate a sine current/voltage suitable for grid connection IEEE929-2000 standards. The overall system has been simulated taking into account environmental effects and standards constraints in order to achieve best performance. The choice of sine band hysteresis control was selected considering its implementation simplicity. The algorithm runs fast on a low-cost microcontroller allowing to avoid any delay that can cause a phase shift in the system. An experimental setup has been realized for tests and validation purposes. Both simulation and experimental results lead to satisfactory results which are conform to the IEEE929-2000 standards.
\end{abstract}

This is an open access article under the CC BY-SA license.

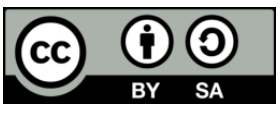

\section{Corresponding Author:}

Della Krachai Mohamed,

Department of Automatics,

University of Science and Technologies of Oran-Mohamed Boudiaf (USTO-MB), Algeria.

Email: mohamed.dellakrachai@univ-usto.dz

\section{INTRODUCTION}

Distributed power generators present an alternative solution for connecting renewable energy sources to the grid. These power sources are obtained from diverse natures: solar, wind, etc. Algeria has a benefit to receive about 1700 to $2600 \mathrm{kWh} / \mathrm{m} 2 /$ year of solar energy [1]. This qualifies solar energy as a primary renewable to be used. In order to harness this energy as a DG, the power systems that interface PV generator to the grid must be well designed to satisfy grid connection criteria. The power is coming from a PV generator that, in place converts sunlight into electricity. A nonlinear relationship exists between the delivered power and the output voltage. In order to use efficiently PV generators, they must be operated in their maximal power, which is highly dependent on environment. Artificial intelligence has been widely used in this operation. Neural networks [2-4] Fuzzy logic [5-8] were applied successfully in tracking the maximal generated power.

On the AC side, in order to connect PV generators to grid, the inverter must be controlled to produce a high-quality sine wave according to the international standards. Hysteresis current control [9-12] has been proposed to satisfy these requirements. Other works proposed current control strategy [13,14] to provide balanced output current and reduce the Total Harmonic Distortion (THD), achieving unity power factor (UPF) [15], compensate for the harmonic current content of the grid current and microgrid without the use of any compensation devices [16], injection of balanced clean currents to the grid [17]. In this paper, efficiency of the system is considered as a major factor and the proposed system is build around practical 
considerations: maximizing the power issued from PV generators and produce proper AC power to be delivered to the public grid utility in accordance to IEEE929-2000 standard [18].

\section{LAYOUT OF THE PROPOSED SYSTEM}

The bloc diagram of the system under investigation is shown in Figure 1. As depicted in this figure, sun light is converted through PV panels to a DC power which is not necessarily the maximal amount due to its considerable dependency on environmental conditions, such as insolation and temperature. MPPT bloc is used to achieve tracking the maximal power regarding any of these conditions. Fuzzy logic is used for that purpose. Once the panels operate at MPP, inverter is used to allow power to flow to the grid side by converting it to AC power. A control system built-around a synchronization mechanism and sine-band hysteresis commutation is implemented to satisfy the standard of connexion at point of common coupling (DC component and THD parameters of the AC shape at the output of the inverter).

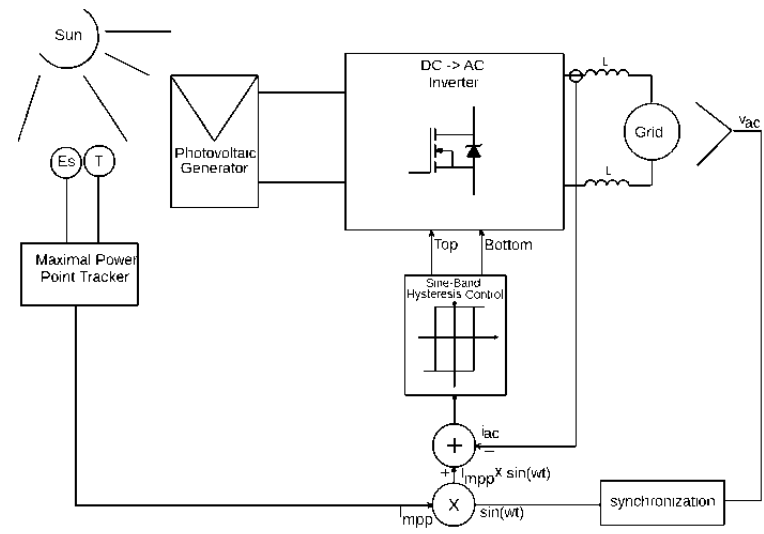

Figure 1. Proposed system components

\subsection{PV panels}

PV panels are collection of PV-cells in series represented by their equivalent circuit given in Figure 2(a). The I-V relationship of produced entities divides the operation of PV panels into three modes (Figure 2(b)). As constant voltage on the right-side where the panel output resistance is very low. On the left-side the panel is viewed as a constant current source. Between these two regions lies the maximal power point in which the panels operate in maximal efficiency.

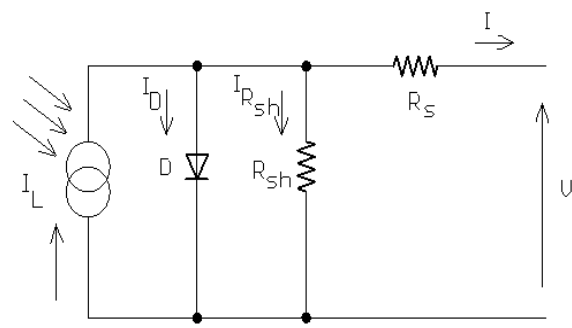

(a)

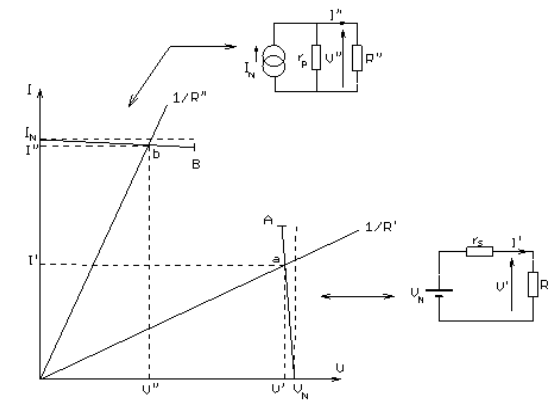

(b)

Figure 2. (a) Equivalent electrical circuit of a PV cell, (b) Modes of operation of PV panels

The electrical characteristics of PV panels (I-V-P) are subject to surrounding environment, most importantly insolation level and temperature. Table 1 shows the electrical characteristics of the panel used in the system. Figure 3(a) and 3(b) give a plot of their impact. It is observed that insolation variations influence 
considerably the produced power comparing to temperature changes. Monitoring these variations is important to have enough information about MPP location.

Table 1. Characteristics of the PV panel used in the system

\begin{tabular}{lc}
\hline \multicolumn{3}{l}{ Soltech } & STH-2 & P-P $\left(1000 \mathrm{~W} / \mathrm{m}^{2}, 25 \mathrm{degC}\right)$ \\
\hline Pmax & $213.15 \mathrm{~W}$ \\
Voc & $36.3 \mathrm{~V}$ \\
Isc & $7,84 \mathrm{~A}$ \\
Vmp & $29 \mathrm{~V}$ \\
Imp & $7,35 \mathrm{~A}$ \\
\hline
\end{tabular}

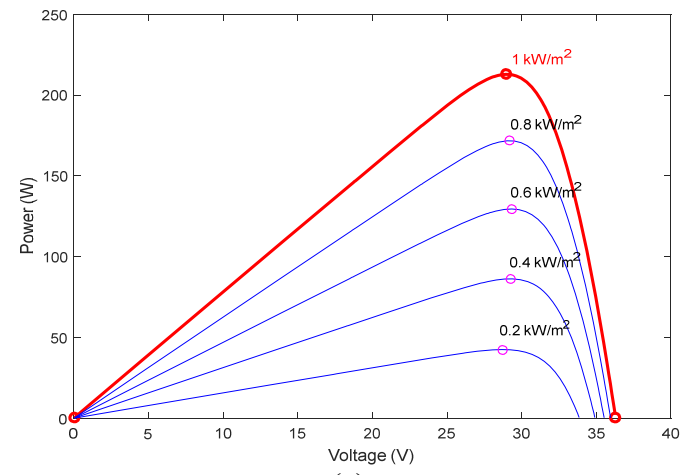

(a)

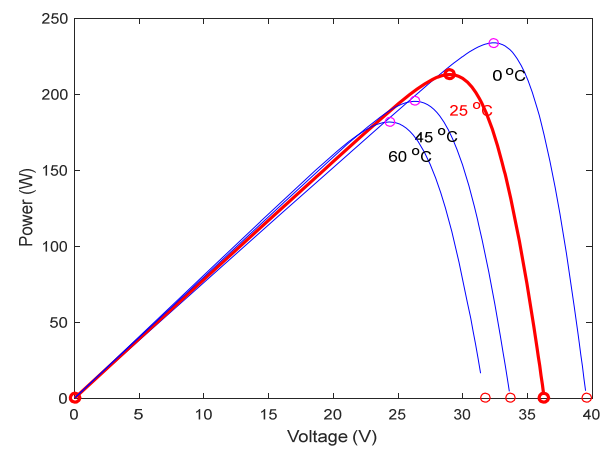

(b)

Figure 3. (a) Insolation influence on produced power, (b) Temperature influence on produced power

\subsection{Maximal power point tracking}

As todays microcontrollers allow fast and complex computations, this makes easier the task of implementing artificial intelligence algorithms [15-17, 19, 21, 22, 25, 26]. Fuzzy logic system is developed to track the MPP location. This system is a complex algorithm that maps the physical inputs (Es, T) to a fuzzy representation though a set of membership functions. Depending on degrees of membership (projection of inputs or fuzzy sets) a number of selected rules are activated. These rules are then inferred to produce a decision (s). An aggregation of these decisions makes the output. As a final phase, a defuzzification (mapping from fuzzy space to real space) outputs the location of the maximal available power corresponding to the presented inputs $(\mathrm{Es} / \mathrm{T})$. The complexity of designing such a system resides in two parts: membership functions (their numbers, their shapes) and the rules that govern the operation of the system which must be formulated by an expert. Adaptive neural fuzzy inference systems, ANFIS have been proposed to optimize an initial FIS using neural networks to map a set of (input/output) data. This dataset is gathered from the PV panel in use. As observed from Figure 3(a), insolation impact is dominant. That qualifies it as a major factor to consider in designing the fuzzy membership functions. After training the network to learn input/output dataset, the resulting FIS reveals the input/output membership functions and fuzzy rules that were hidden underneath this numerical data. Figures 4(a) and 4(b) show the membership functions for the initial and optimized FIS

These results confirm the conclusion extracted from the previous section. The maximal power is highly depending on insolation and not considerably on temperature. The surface (Figure 5) that maps the output current Impp respectively to the inputs Isc (Es) and Voc (T) of the optimized fuzzy inference system shows the highly non-linear relationship that exists between these entities. 


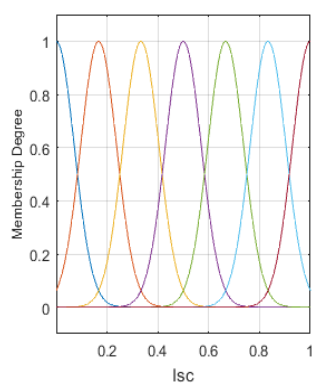

(a)

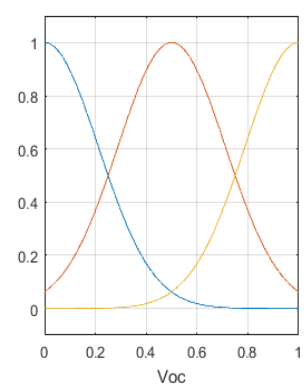

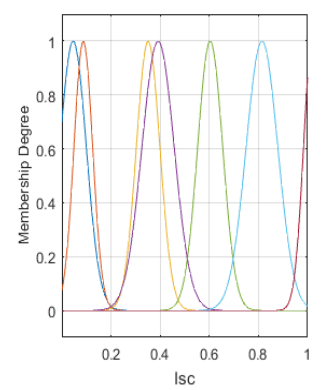

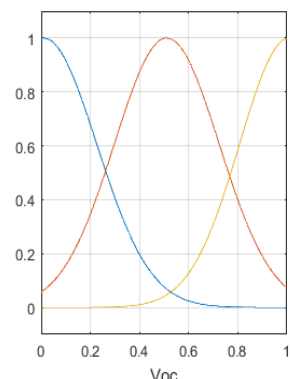

(b)

Figure 4. Fuzzy MFs for (a) initial FIS and (b)optimized FIS

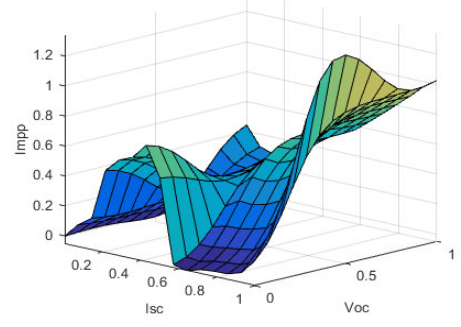

Figure 5. Fuzzy inference system surface

\subsection{Inverter control and grid synchronization}

The synchronization is achieved by measuring the sine voltage at the point of common coupling (PCC) through an attenuation transformer $[18,20,23,24]$. This sine wave is reduced to $1 \mathrm{~V}$ magnitude which is then multiplied by the Impp (maximal PV current from MPPT) to produce the reference AC current.The inverter output current is compared against the reference current and the difference is controlled to vary within a sine-band hysteresis that produces the commutation pulses to the transistors of the inverter. Figure 6 shows the operation mechanism of the AC side.

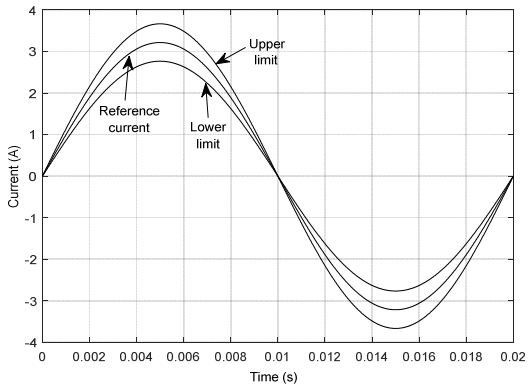

(a)

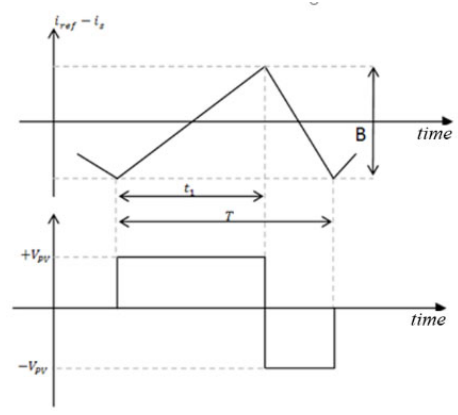

(b)

Figure 6. Sine-band hysteresis control principle

\section{SIMULATION RESULTS}

Assembling all subsystems and considering some scenarios, the following results are issued. Figure 7 shows the produced current and power from PV panels for an increasing insolation level. Figure 7(a) 
presents the position of the MPP on the PV curves and Figure 7(b) the corresponding evolution of the maximal available current at the output of the PV panels. It is observed that the tracking performance is satisfactory and the efficiency of the DC side is optimized.

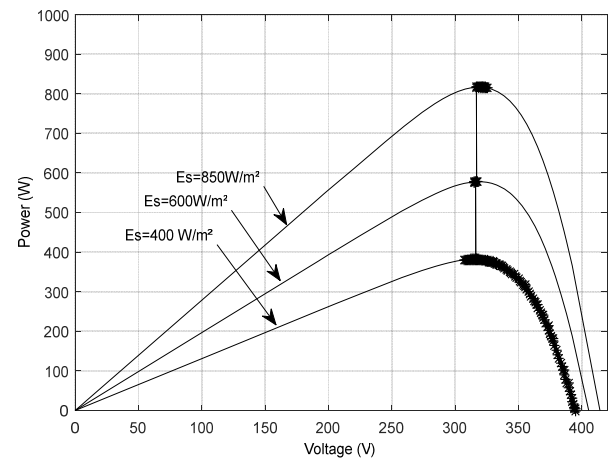

(a)

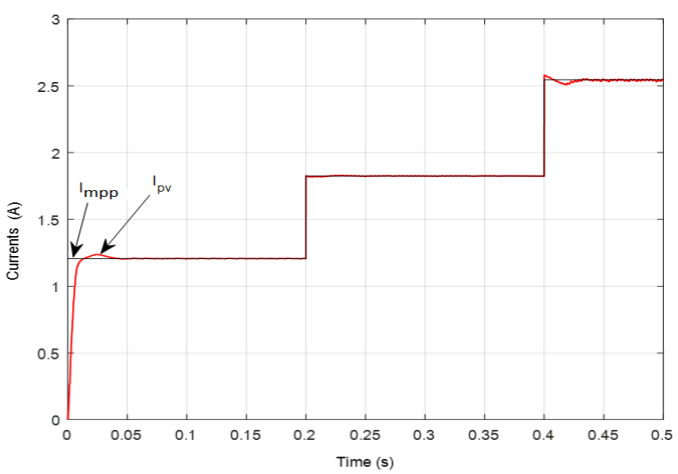

(b)

Figure 7. MPP tracking performance

On the Ac side, Figure 8(a) shows that the inverter current is in phase (synchronous) with a grid voltage achieving a unity power factor (active power) while Figure $8(\mathrm{~b})$ shows the sine-band hysteresis controller pulses produced to drive the inverter transistors. It is observed that the number of commutations increases around zero-crossing of the grid voltage inversely proportional to the hysteresis band width.

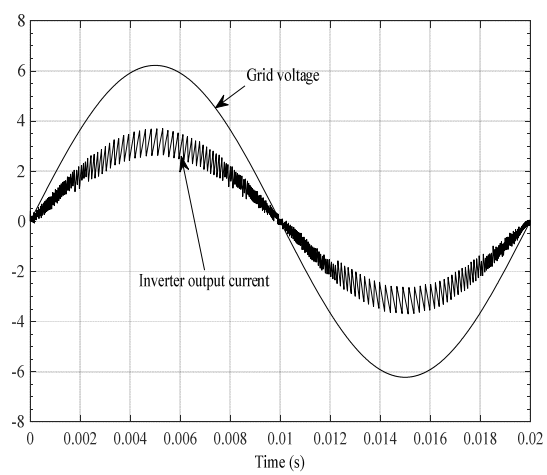

(a)
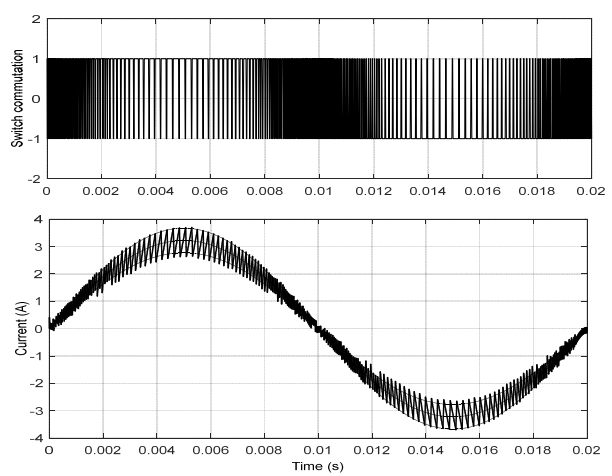

(b)

Figure 8. Grid side outputs

\section{EXPERIMENTAL REALISATION AND RESULTS}

In order to make real conclusions, an experimental prototype (Figure 10) has been developed. Figure 9, shows the hardware implementation principle of the prototype. A pilot cell is used to measure the short circuit current Isc which represents the image of the insolation Es, and the open-circuit voltage Voc the image of the temperature $\mathrm{T}$. These two measurements are converted through the ADC of the microcontroller dsPIC30F4011 to a numerical value used as inputs of the MPP tracker. A timer is programmed to schedule the MPP tracking task. On the AC side, the grid voltage is attenuated by a stepdown transformer and filtered. The resulting signal is used to produce digital pulses corresponding to zero crossing of the waveform. A look-up table whose values consist of a digitized unity magnitude sine wave with $50 \mathrm{~Hz}$ frequency is programmed in the Flash memory of the microcontroller. Each zero-crossing of 
the grid voltage an interrupt is generated. This interrupt instructs the microcontroller to reset the index of the look-up table to the top position, and engages a second timer to scan the table values.

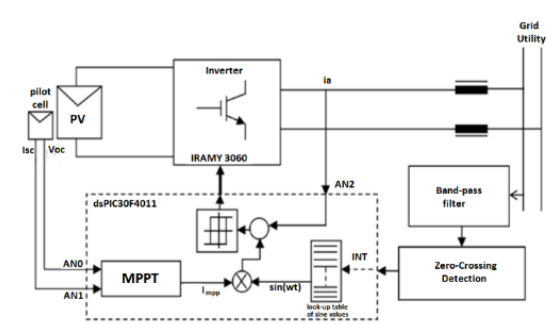

Figure 9. Prototype implementation details

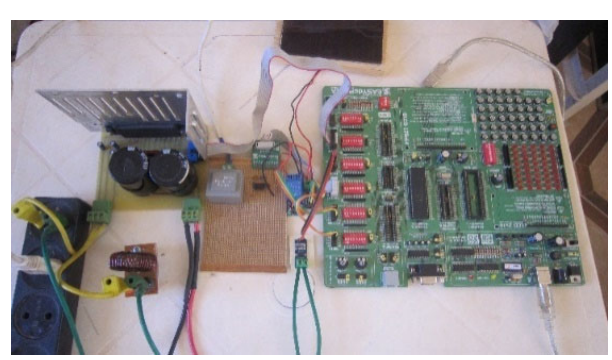

Figure 10. Experimental developed prototype

On each timer step, the corresponding sine value is multiplied by the I_mpp to give the reference current i_(ac_ref) $\left(\mathrm{t} \_\mathrm{k}\right)=\mathrm{I} \_\mathrm{mpp} \sin \left(2 \pi 50 \mathrm{t} \_\mathrm{k}\right)$ which is compared to the measured current $\left.\mathrm{i}\right]_{-} \mathrm{ac}\left(\mathrm{t} \_\mathrm{k}\right)$. The comparison error is compared against a sine hysteresis bands to fire the transistors of the inverter in order to keep current growing inside these bands. Figure 11.a gives the inverter output current and the corresponding transistor firing signal. The dark region in the firing signal is the high frequency pulses that are produced around zero-crossing. A closest look at this region is given in figure 11.b. This is caused by the sine band of the hysteresis controller. Figure 12 depicts the scaled down grid voltage and the inverter output current. Both signals are in phase which leads to a unitary power factor. It is also observed from figure 13 that the current signal has a very low THD (around $2.86 \%$ calculated using the 21 th first harmonics) and a near-zero DC component. This satisfies the IEEE929-2000 standard requirements.

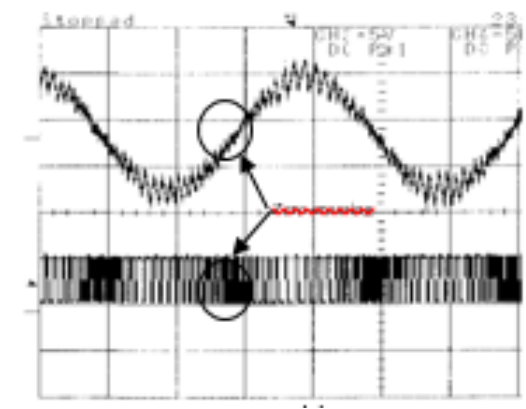

(a)

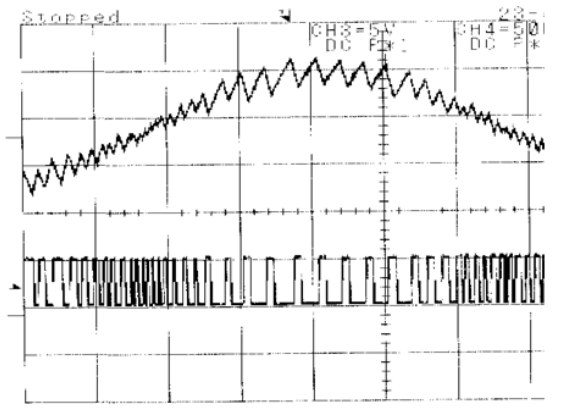

(b)

Figure 11. The inverter (top trace) output current and (bottom trace) commutation signal

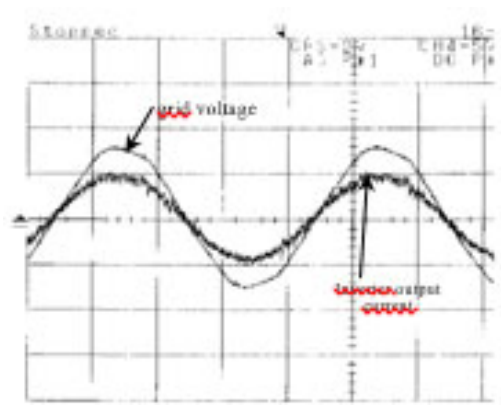

Figure 12. Grid voltage and inverter output current

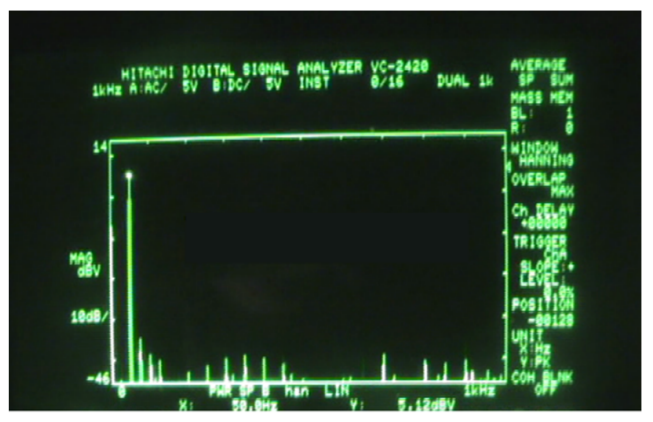

Figure 13. THD of the output current 


\section{CONCLUSION}

Fuzzy inference systems have been applied successfully in MPP tracking for PV-Grid connected plants. It is shown that high performance tracking is achieved, optimizing thus the efficiency of the whole system. On the AC side, sine band hysteresis current is used to control the inverter considering the standard requirements IEEE 929-2000 in terms of current harmonics (THD) and DC component contents. Hysteresis band has been optimized taking into consideration standard recommendations and switching limitations of the inverter transistors. Simulations as well as experimental results demonstrate the performance of the proposed controllers and their simplicity of implementation.

\section{REFERENCES}

[1] M. Capderou, " Atlas solaire de l'Algérie, " Office des publications universitaire, Tomes 1, 2, et 3,1987.

[2] T. Hiyama, S. Kouzuma \& T. Imakubo, "Identification of Optimal Operating Point of PV Modules using Neural Network for Real Time Maximum Power Tracking Control," IEEE Trans. on Energy Conversion, Vol. 10, 1995.

[3] Mohamed Keddar, Mamadou Lamine Doumbia, Mohamed Della, Karim Belmokhtar, Abdelhami Midoun, "Interconnection Performance Analysis of Single-Phase Neural Network Based NPC and CHB Multilevel Inverters for Grid-connected PV Systems", International Journal of Renewable Energy Research-IJRER, Vol. 9, No. 3 (2019)

[4] Mohamed Keddar, M.L. Doumbia, Karim Belmokhtar, M. Della Krachai, A.H. Midoun, "Experimental Validation of Photovoltaic Grid Connected NPC Multilevel Inverter Based on Neural Network MPPT", International Conference on Wind Energy and Applications in Algeria (ICWEAA), 2018

[5] T. Ramesh, R. Saravanan, S. Sekar," Analysis of ANFIS MPPT Controllers for Partially Shaded Stand- Alone Photovoltaic System with Multilevel Inverter, "International Journal of Robotics and Automation (IJRA), vol. 7, No. 2, pp. 140 148, Jun 2018.

[6] R. Arulmurugan, Swapna Sandaraju, " An ANFIS Converter Control Approach of Grid Connected Wind/PV/Sattery system, " International Journal of Robotics and Automation (IJRA), vol. 8, No. 1, pp. 6 17, Mar 2019

[7] S. Della Krachai, A. Boudghene Stambouli, M. Della Krachai, M. Bekhti, "Experimental investigation of artificial intelligence applied in MPPT techniques", International Journal of Power Electronics and Drive System (IJPEDS), Vol. 10, No. 4, pp. 2138-2147, 2019.

[8] L. Atik, P. Petit, J.P. Sawicki, Z.T. Ternifi, G. Bachir, M. Della, and M. Aillerie, "Maximum Power Point Tracking algorithm based on sliding mode and fuzzy logic for photovoltaic sources under variable environmental conditions", Technologies and Materials for Renewable Energy, Environment and Sustainability AIP Conf. Proc. 1814, Paris , November 2016

[9] S. Raja Mohamed, P. Aruna Jeyanthy, D. Devaraj, " Hysteresis-based Voltage and Current Control Techniques for Grid Connected Solar Photovoltaic Systems: Comparative Study," International Journal of Electrical and Computer Engineering (IJECE), Vol. 8, No. 5, pp. 2671 2681, Oct 2018.

[10] N. Chaitanya, P. Sujatha, K. Chandra Sekhar, " Current Controller Based Power Management Strategy for Interfacing DG Units to Micro Grid, " International Journal of Electrical and Computer Engineering (IJECE), Vol. 7, No. 5, pp. 2300 2308, Oct 2017.

[11] J. Kaduim Abed, " A Three Phase Photovoltaic Grid Tied Tnverter System Control Based on T-S Fuzzy Equalization, " International Journal of Power Electronics and Drive System (IJPEDS), Vol. 10, No. 2, pp. 928 934, Jun 2019.

[12] M. Yaich, M. Ghariani, " A Novel Technique for Tuning PI-controller in Switched Reluctance Motor Drive for Transportation Systems," International Journal of Electrical and Computer Engineering (IJECE), Vol.8, No. 6, pp. 4272 4281, Dec 2018.

[13] A. Naderipour, Z. Abdul-Malek, E. Abohamzeh, Vigna K. Ramachandaramurthy, M. R. Miveh, "Control strategy of Grid-Connected PV Inverters in Microgrid with Nonlinear Operating Conditions" IEEE 7th International Conference on Power and Energy (PECon), 2018

[14] A Naderipour, Z. Abdul-Malek, M. R. Miveh, M. J. A. Moghaddam, A. Kalam, and F. H. Gandoman, " A Harmonic Compensation Strategy in a Grid-Connected Photovoltaic System Using Zero-Sequence Control", Energies 2018, 11, 2629; doi:10.3390

[15] A Naderipour, Z. Abdul-Malek and J. M. Guerrero "Control Method for Three-Phase Grid-Connected Inverter PV System Employing Unity Power Factor (UPF) Strategy in Microgrid", CEEGE 2019, DOI: $10.1051 / \mathrm{e} 3 \mathrm{sconf} / 201911501006$

[16] Naderipour, A. A. Mohd Zin1, M. H. Bin Habibuddin, M. R. Miveh, J. M. Guerrero, "An improved synchronous reference frame current control strategy for a photovoltaic grid-connected inverter under unbalanced and nonlinear load conditions", PLOS ONE, DOI:10.1371/journal.pone.0164856, 2017

[17] Asuhaimi Mohd Zin, A.; Naderipour, A. ; Habibuddin, M.H.; Guerrero, Josep M., "Harmonic currents Compensator Grid-Connected Inverter at the Microgrid”, IET, Electronics Letters, 2016, 52(20), 1714 - 1715.

[18] IEEE Std 929-2000, "IEEE Recommended Practice for Utility Interface of Photovoltaic (PV) Systems, DOI: 10.1109/IEEESTD.2000.91304, 2000.

[19] M. Keddar, M.L. Doumbia, K. Belmokhtar, M. Della Krachai, "A New Energy Strategy of an Autonomous Microgrid based on Virtual Impedance in Multilevel Droop Controlled Inverters", 2019 The International Conference on Advanced Electrical Engineering, Algiers, Algeria (ICAEE2019) 
[20] D. Sattianadan, V. Kalyanasundaram, S. Vidyasagar, Deepak Kumar Nayak, Roopam Jha, "Maximum Power Point Tracking for a Grid Connected Photovoltaic System Using Sliding Mode Control”, International Journal of Power Electronics and Drive System (IJPEDS), Vol. 8, No. 4, pp. 1785 1792, December 2017.

[21] Samosir A. S., et al., "Modeling and Simulation of Fuzzy Logic based Maximum Power Point Tracking (MPPT) for PV Application," International Journal of Electrical and Computer Engineering (IJECE), Vol. 8, No. 3, pp. 1315-1323, 2018.

[22] Manoharan P., et al., "A Comparative Study and Analysis on Conventional Solar PV Based DC-DC Converters and MPPT Techniques," Indonesian Journal of Electrical Engineering and Computer Science, Vol. 11, No. 3, pp. 831-838, 2018.

[23] Y. Yang and F. blaabjerg, "Overview of single-phase grid connected photovoltaic systems", Electric Power Components Systems, Vol. 43, No. 12, pp. 1352-1363, Jul. 2015.

[24] M. Parvez, M. F. M. Elias, N. A. Rahim, and N. Osman, "Current control techniques for three-phase grid interconnection of renewable power generation systems: A review", Solar Energy, Vol. 135, pp. 29-42, 2016.

[25] Abdelhadi Bouknadel, Naima Ikken, Ahmed Haddou, Nour-Eddine Tariba, Hafsa El Omari, Hamid El Omari, "A new SOGI-PLL method based on fuzzy logic for grid-connected PV inverter," International Journal of Electrical and Computer Engineering (IJECE), Vol. 9, No. 4, pp. 2264-2273, DOI: 10.11591/ijece.v9i4, 2019

[26] L. Hassaine, M. R. Bengourina, "Design and digital implementation of power control strategy for grid connected photovoltaic inverter", International Journal of Power Electronics and Drive System (IJPEDS), Vol. 10, No. 3, Sep 2019, pp. 1564 1574

\section{BIOGRAPHIES OF AUTHORS}

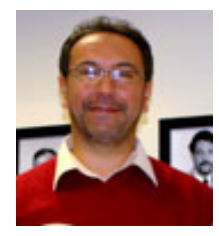

Della Krachai Mohamed was born on 29.09.1973 in Oran Algeria. In 1996 he graduated at the Electronics Department of the Faculty of Electrical Engineering at University (USTO) in

Algeria. He obtained his "Magister". In the field of power electronics and photovoltaic systems in 2000; and the $\mathrm{PhD}$ degree in 2009. Actually he is interested in power electronics and in renewable energies (wind and solar energy).

E-mail: mohamed.dellakrachai@univ-usto.dz

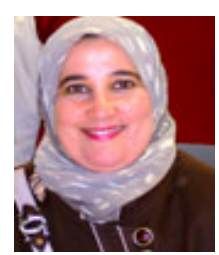

Melouk kheira was born in Sidi Belabbes (Algeria), on December 25, 1972

In 1995 she graduated at the Electronics Department of the Faculty of Electrical Engineering at Sidi Belabbes University (Djillali Liabes) in Algeria. She defended her "Magister" in the field of Optoelectronics in 1999; her thesis title was "Design and optimization of semi-conductor laser", and the $\mathrm{PhD}$ degree in 2010; Her scientific research is focusing in blue semiconductor lasers. Actually, she is interested in regulation and control in system.

E-mail: mlkkhr1@gmail.com@gmail.com

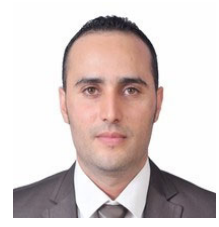

Mohamed Keddar is actually a Phd student at UQTR (Université du Québec à Trois-Rivières) Faculty of Electrical and Computer Engineering, Canada. His scientific research is focusing in power electronics, smart grids and renewable energies.

E-mail: mohamed.keddar@uqtr.ca 